(C) 2021 Zhizhko. This article is distributed under the terms of CC Attribution-Share Alike 4.0 International described at https://creativecommons.org/ licenses/by-sa/4.0

DOI:

UDC: $378.014(438)$

\title{
LEARNING STRATEGIES FOR BASIC CONCEPTS OF MECHANICS IN MECHANICAL ENGINEERING DEGREE PROGRAMS. MEXICAN EXPERIENCE
}

\author{
Gali Aleksandra Beltrán Zhizhko \\ PhD, Associate Professor, \\ Technologic University of Durango, Mexico \\ http://orcid.org/0000-0001-7186-332X; e-mail: gali.beltranzh@gmail.com
}

This article presents the results of the pedagogical study, which objective was to establish the scope of the conceptual maps carried out with CmapTools in the learning of basic concepts of classical mechanics by metallurgical engineering students in National Polytechnic Institute of Mexico and to identify the way in which such concepts are learned. Author founds, that students, by creating conceptual maps on the basic concepts of mechanics with CMapTools with good content quality evaluated with a semantic evaluation rubric, improved their understanding of these concepts, according to the Force Concept Inventory (FCI) questionnaire and increased their motivation to study these aspects of mechanics. Therefore, the creation of conceptual maps with CMapTools affects positively the significant learning of the basic concepts of classical mechanics.

Key words: Mexican experience in Professional Education; teaching methodology in Mechanical Engineering Degree Programs; learning strategies for basic concepts of mechanics; creation of conceptual maps with CmapTools.

У иій статті представлені результати педагогічного дослідження, метою якого було Встановлення обсягу концептуальних карт, здійснених за допомогою CMapTools nid час вивчення основних понять класичної механіки студентамиметалургійними інженерами В Національному політехнічному інституті Мексики та Визначення шияху як такі поняття засвоюються. АВтор ВияВив, що студенти, створивши концептуальні карти з основними поняттями механіки за допомогою CMарTооls з гарною якістю контенту, оціненого за допомогою рубрики семантичної оцінки, покращили своє розуміння цих понять згідно з опитувальником Ғогсе Cопсерt 
Inventory (FCI) та підвищили свою мотивацію. Вивчати ці аспекти механіки. Тому створення концептуальних карт за допомогою CMapToоls позитивно впливає на значне вивчення основних понять класичної механіки.

\begin{abstract}
Ключові слова: мексиканський досвід професійної освіти; методика Викладання за освітніми програмами «Інженер-механік»; стратегї вивчення основних понять механіки; створення конщептуальних карт за допомогою CmapTools.
\end{abstract}

Introduction. Physics is one of the foundations of engineering, therefore, it is essential that the student of any engineering career understands the basic concepts and principles of this science. One of the main problems for students when learning the subject of classical mechanics is that many times the teaching-learning process is based on memorizing formulas and solutions, and not on understanding and applying its fundamental principles. As well, the majority of university-level students present deficiencies in the understanding of basic mechanics concepts that could not be resolved during the stages of basic and upper secondary education, due to various factors, both external and internal to the student.

How can the learning of basic concepts of classical mechanics be favored in engineering careers? In this sense, the methodological experience with the Metallurgical Engineering career of the National Polytechnic Institute of Mexico could be useful, in particular, the creation of concepts maps with CmapTools in the matter of Applications of Mechanics in the Metallurgical Engineering of the Interdisciplinary Professional Unit of Engineering Campus Zacatecas of the National Polytechnic Institute of Mexico.

To the problem of teaching classical mechanics at a university level dedicated their work Latin American researchers such as Bandiera, Dupre, Ianniello, \& Vicentini, 1995; Salinas, Cudmani, \& Pesa, 1996; Mora \& Herrera, 2009; Pedraza \& Sánchez, 2011; Maloney, 1994; Guisasola, Furio, Ceberio, \& Zubimendi, 2003; Gil \& De Guzmán, 1993, among others. Scientists agree that in most cases the model of this teaching remains traditional, therefore, it has not been possible to disappear the formative deficiencies of students, as well as longterm learning problems, erroneous preconceptions or inappropriate study strategies. Hence, modifications are suggested in the strategies used in order to motivate the student and achieve a meaningful learning.

This can be achieved with the use of ICT, digital tools that can be used in classrooms in order to improve the student's learning experience. However, the simple use of technology in the classroom is not enough to achieve meaningful learning in the student. It is necessary to make a change in the entire learning environment, from the teaching methodology, the didactic materials, to the activities and communication in the classroom.

The purpose of the article. The objective of this research was to establish the scope of conceptual maps with CmapTools in the learning of basic concepts of mechanics by the students of Metallurgical Engineering in the Interdisciplinary Professional Unit of Engineering Campus Zacatecas of the National Polytechnic Institute of Mexico and to identify the way in which those concepts are learned. 
Methodology. The research was carried out following the methodology described next. A didactic strategy mediated by CmapTools was designed. The concept mapping was tracked in two phases (before-after) as advocated by various theorists regarding meaningful learning. During phase I (before), a diagnosis of the students was made where they created an initial conceptual map to observe the degree of understanding of the concepts, measured with a force concept questionnaire (Force Concept Inventory or FCI). The students then made a concept map during the classes and at the end, in phase II, another observation was made regarding their understanding of concepts using the FCI questionnaire again.

Results. The most recent studies by Latin American researchers related to the subject of didactic strategies mediated by ICT applied to basic science courses, such as physics, chemistry or mathematics, generally show that this type of strategies have a positive impact in academic improvement for students, increasing their motivation and interest in those subjects (Gómez Mercado \& Oyola Mayoral, 2012; Rodríguez, Cegarra, \& Díaz Caceres, 2014).

The studies carried out regarding the use of concept maps in teaching, in general conclude that the application of this didactic tool allows students to be more motivated to do the activities, to be more responsible in the construction of their own knowledge, to be able to visualize the relationships between concepts, to organize and to express their ideas, to prioritize information and to organize models based on it. Concept maps can help students "learn to learn", facilitate collaborative work and gain a deeper knowledge.

In the teaching of physics, behavioral learning theories, which favor mechanical learning, are very common. This is a type of learning that is not recommended, since students only memorize formulas, definitions and correct answers to later reproduce them in tests, and do not acquire long-term learning.

On the contrary, according to the cognitive and constructivist theories, the learning should be significant and it requires the understanding and construction of meaning. The student builds his knowledge from his own thinking and interpretation of the information, so he must be someone who actively participates in the learning process.

To learn a content means that the student attributes a meaning to it, builds a mental representation with the help of images or words, or makes a certain mental model to explain the said knowledge (Díaz Barriga \& Hernández, 2002). This notion of meaning construction refers to Ausubel's Theory of Meaningful Learning, which is the theoretical basis of this research.

The Theory of Meaningful Learning, created by Ausubel, explains how cognition is produced. This theory centers the attention on the learner, on what happens in the classroom when someone is learning, in the nature of this learning, in the conditions needed to produce the learning, on its results and its evaluation. For these reasons the present study of the application of concept maps for the understanding of mechanical concepts is based on this theory.

"Meaningful learning" is a fundamental notion in educational psychology and is the central concept of Ausubel's theory. It refers to the process by which the learner relates a new knowledge in a non-arbitrary and substantive way with his previous knowledge. 
The non-arbitrariness of meaningful learning represents the relationship between the materials to be learned with the pre-existing knowledge in the student's mind. From this, it can be said that the important thing is that the student has relevant information and concepts that are clear and available, which will allow the incorporation and understanding of new knowledge.

Concept maps are tools that can help the learner to structure the knowledge or concepts that already exist in their cognitive structure, so that the new information to learn is easier to "anchor" to the previous knowledge.

The substantivity characteristic means that what matters is the content and the background of the new knowledge that is acquired, not the precise words used to express those new ideas.

Ausubel's theory is a classroom learning theory, it explicitly presents principles and strategies that can be put into practice. In this research, an analysis of the content of the subject was carried out to identify the basic concepts that the student needs to understand, and through concept maps an attempt was made to relate these ideas with the relevant previous ideas of the student's cognitive structure.

However, there is a problem when the student relates new knowledge with previous ideas derived from their common sense, especially in physics. The student creates through his daily experience certain beliefs about the world around him, which are not always compatible with the established concepts of this science. In the present work, this problem was also observed from some of the students and an attempt was made to correct it.

The use of strategies that promote meaningful learning is an alternative method to memorization that is more effective. The concept mapping strategy, developed by Novak, is a technique that emphasizes concepts and their relationships. Concept maps can be used as a didactic, assessment, analysis of the curriculum and as a metacognition tool. In this research, it was decided to use this technique as a didactic resource for students, which helped them to understand basic concepts of mechanics and the relationships between them.

Another important aspect of meaningful learning is student's motivation, which includes his interests and willingness to learn the content. As young people immersed in the knowledge society, surrounded by technologies, the use of ICT in education can help motivate students. This is why the use of a computer program for the creation of concept maps was applied so that the students could rely on it. And, as the results show, most of them reported feeling more motivated with this tool, although there were some who mentioned the opposite, feeling unmotivated since they could not fully understand the operation of the program. For this reason, it is considered that it is necessary in the first instance to explain the operation of the software to be used as a digital tool, and then move on to the generation of learning (in this case, with the creation of concept maps).

There exists various computer programs for creating concept maps, open-ended or proprietary. The open type are free and the private ones are paid. In this research work, the CmapTools software was used so that students could create concept maps with it, since it is open (free), easy and intuitive to use and favors collaborative work.

It should be noted that concept maps can be used at any time during instruction: at the beginning they serve as preliminary organizers; during instruction its function is to 
organize and improve internal relationships between relevant concepts; in the end, they help the student to integrate all the knowledge learned. In this study, concept maps were used during instruction to organize relationships between concepts.

Next, are presented the resulting variables associated with the content of the questions of the initial survey made to the students of the subject of Applications of Mechanics of the Metallurgical Engineering career of the Interdisciplinary Professional Unit of Engineering Campus Zacatecas of the National Polytechnic Institute of Mexico and the categories that correspond to each variable derived from the direct processing of the answers to the questions. The axes of analysis are included and the results of the application of the Force Concepts Inventory (FCI) are reported.

From the analysis of the information obtained from the initial survey to the students, a set of categories was assigned to each of the variables associated with the questions. The survey consists of 10 questions, only the last one is an open question. Table 1 shows the resulting categories that correspond to the content of the answers to the questions.

Table 1.

Axis of analysis, variables and categories associated to the questions of the initial survey.

\begin{tabular}{|c|c|c|c|}
\hline $\begin{array}{l}\text { Axis of } \\
\text { analysis }\end{array}$ & Question & Variable & Categories \\
\hline \multirow{9}{*}{ 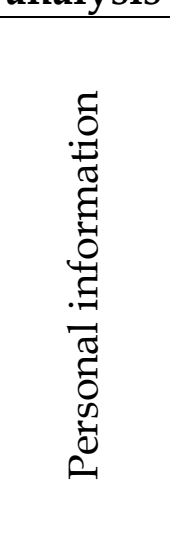 } & \multirow{3}{*}{1} & \multirow{3}{*}{ Age } & 17 \\
\hline & & & 18 \\
\hline & & & 19 \\
\hline & \multirow{2}{*}{2} & \multirow{2}{*}{ Gender } & Male \\
\hline & & & Female \\
\hline & \multirow[b]{2}{*}{3} & \multirow{2}{*}{$\begin{array}{c}\text { Place where they studied } \\
\text { high school }\end{array}$} & In Zacatecas \\
\hline & & & $\begin{array}{l}\text { Outside of } \\
\text { Zacatecas }\end{array}$ \\
\hline & \multirow{2}{*}{4} & \multirow{2}{*}{$\begin{array}{c}\text { Previous training in } \\
\text { physics }\end{array}$} & Yes \\
\hline & & & No \\
\hline \multirow{6}{*}{ 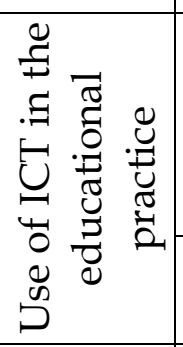 } & \multirow{4}{*}{5} & \multirow{4}{*}{$\begin{array}{c}\text { Frequency of use of digital } \\
\text { tools with educational } \\
\text { purposes }\end{array}$} & All the time \\
\hline & & & Sometimes \\
\hline & & & Rarely \\
\hline & & & Never \\
\hline & \multirow{2}{*}{6} & \multirow{2}{*}{$\begin{array}{l}\text { Use of ICT by the physics' } \\
\text { teacher }\end{array}$} & Yes \\
\hline & & & No \\
\hline \multirow{4}{*}{ 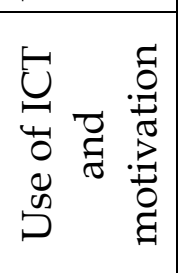 } & \multirow{2}{*}{7} & \multirow{2}{*}{$\begin{array}{l}\text { Motivation in the last } \\
\text { physics course taken }\end{array}$} & Yes \\
\hline & & & No \\
\hline & \multirow[b]{2}{*}{8} & \multirow{2}{*}{$\begin{array}{l}\text { Increase of motivation } \\
\text { with the use of ICT by the } \\
\text { physics professor }\end{array}$} & Yes \\
\hline & & & No \\
\hline
\end{tabular}




\begin{tabular}{|c|c|c|c|}
\hline 9 & $\begin{array}{c}\text { Better understanding of } \\
\text { concepts with the use of } \\
\text { ICT by the physics' } \\
\text { professor }\end{array}$ & Si \\
\cline { 3 - 3 } & 10 & $\begin{array}{c}\text { Factors influencing } \\
\text { motivation }\end{array}$ & Open \\
\hline
\end{tabular}

Figure 1 shows the graph about the age of the students. Most of the students are 18 years old, which is the average age at which they enter to the university. All students have already attended high school.

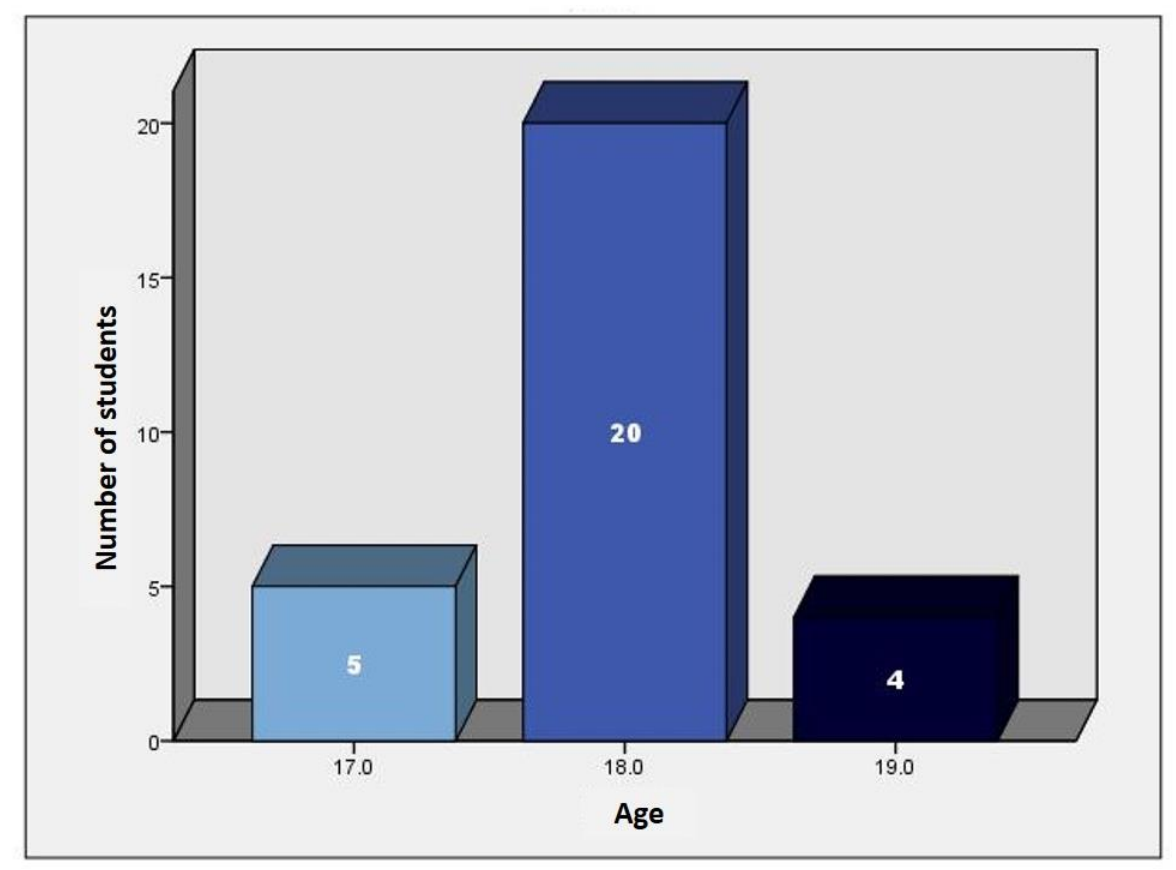

Figure 1. Age of the students

Figure 2 shows the number of students of each gender. Almost $60 \%$ of students are men, predominating over women. In engineering, this predominance of male students over female is usually observed; and yet, the difference in the investigated group is not so great, so it can be considered that the gender gap is closing little by little. 


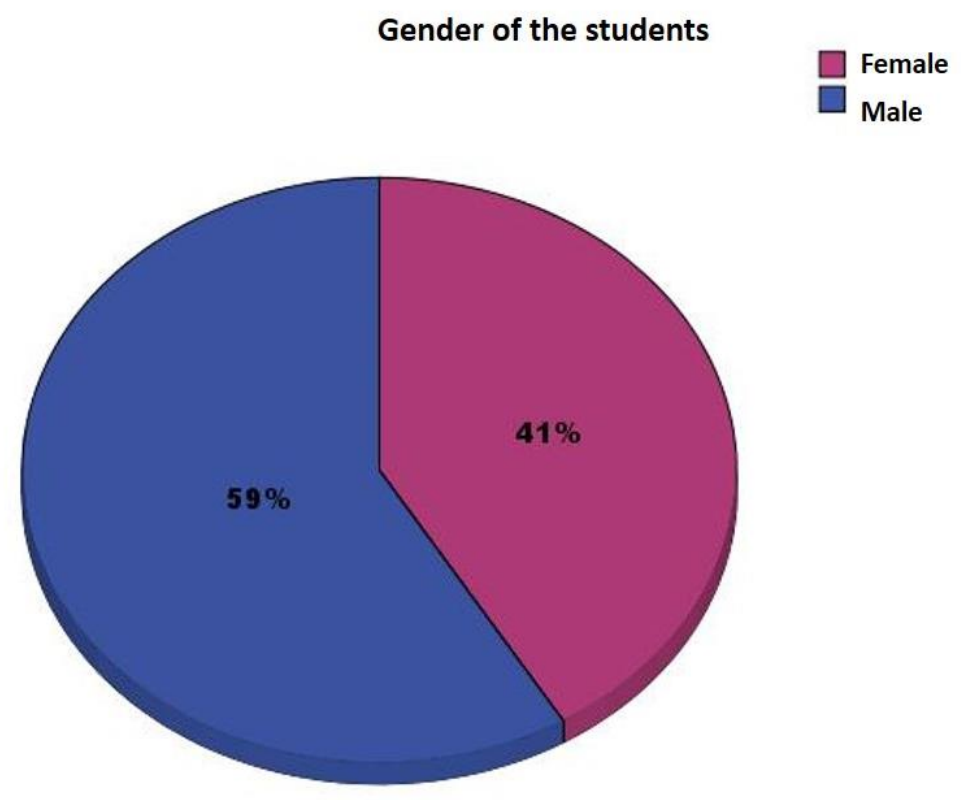

Figure 2. Gender of the students

The following figure (figure 3) shows the number of foreign students (they carried out previous studies outside of Zacatecas) and local students (previous studies carried out in Zacatecas). More than $60 \%$ of the students in the group are from a municipality outside the city of Zacatecas. Not being with their families and perhaps living alone, or taking longer trips to go to their classes, can be an emotional factor that affects the student's academic achievement.

On the other hand, technological tools can be helpful for foreign students, by letting them to carry out work from the computer and to have constant communication with their teacher or their classmates, to solve doubts and to receive feedback. 


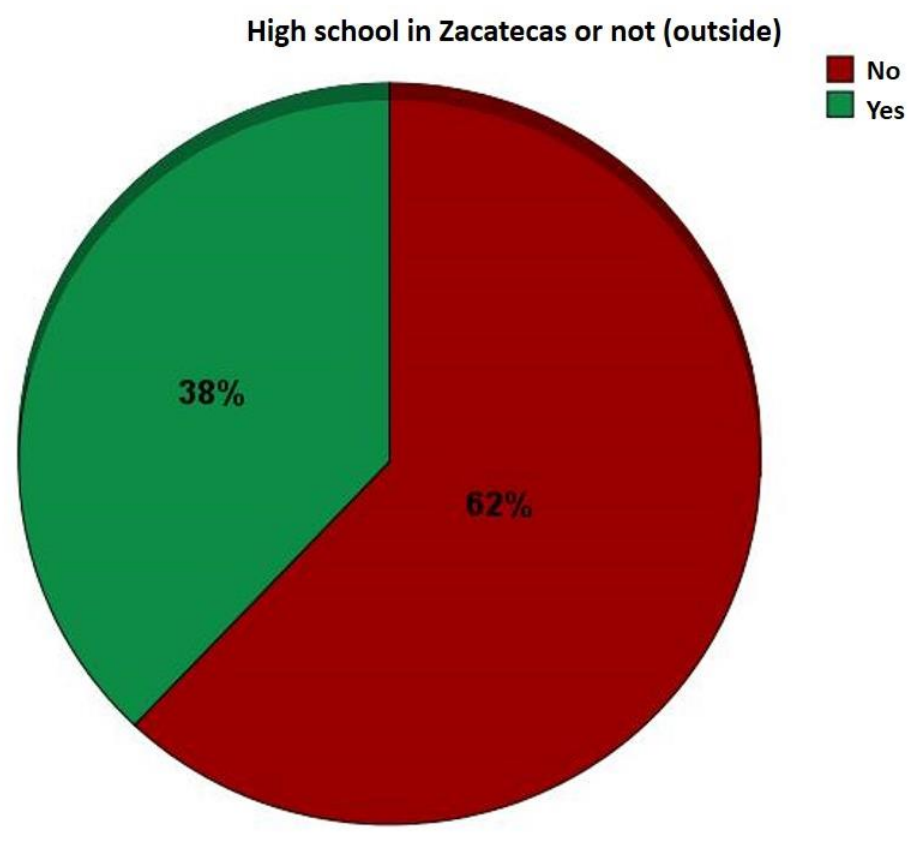

Figure 3. The student carried out previous studies in Zacatecas (yes) or outside (no).

Regarding previous training in the area of physics, $100 \%$ of students mention having had at least one physics subject during their high school studies; so it is considered that everyone already has certain previous ideas about the main concepts of physics, and therefore, Newtonian mechanics.

For the following axis of analysis: use of ICT in educational practice, students were questioned about the frequency with which they use technologies for educational purposes, finding that $45 \%$ use ICT all the time for educational purposes, another $45 \%$ use them a few times, while $7 \%$ use them rarely and $3 \%$ have never used technological tools for any educational purpose (figure 4).

Most young people today make use of different technological tools to support their learning; a minority do not use technologies for this purpose, probably due to misinformation or lack of access to them. As already mentioned, this is a gap that still needs to be closed.

These figures show us that the majority of students in the Applications of Mechanics group have access to ICT and know how to use them for educational purposes. 


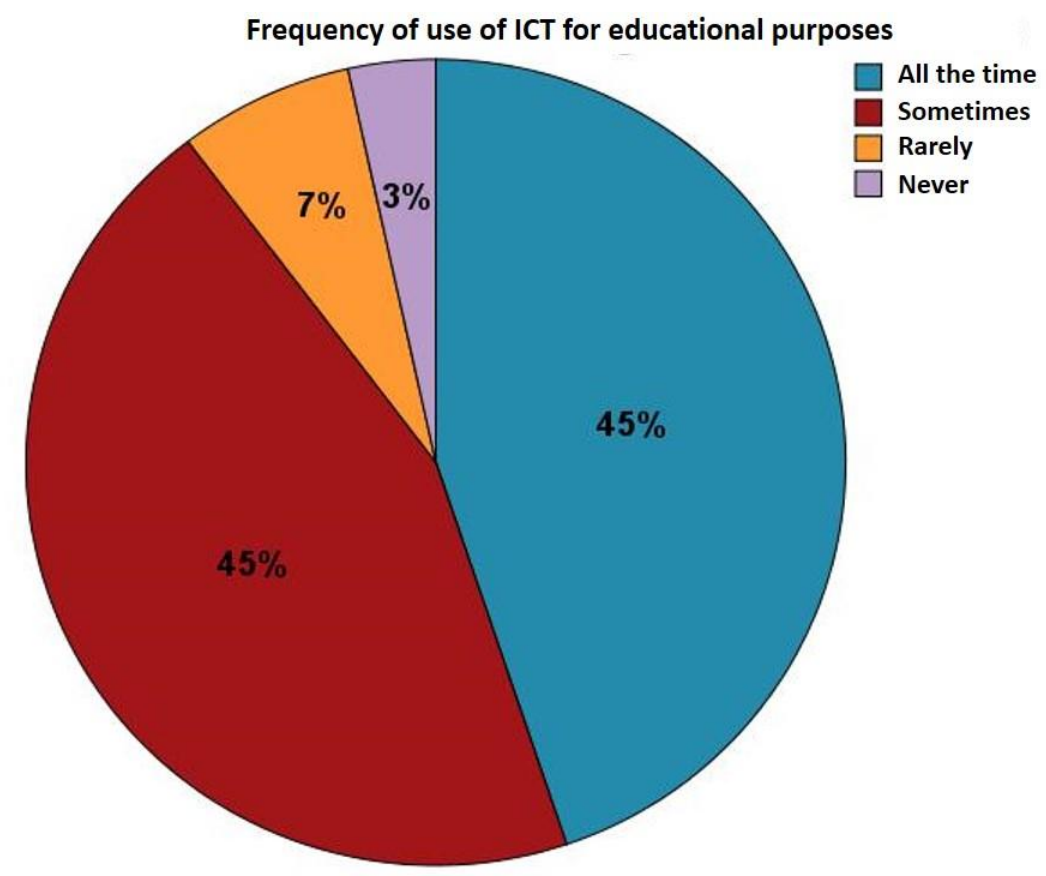

Figure 4. Frequency of use of ICT by students in the educational practice.

Regarding the use of ICT by physics' teachers, 52\% of students affirmed that technological tools were used by their physics teacher, while $48 \%$ commented that they were not used (figure 5). Therefore, approximately half of the students never used information technology specifically in the field of physics; which indicates that there are still many possibilities regarding the application of technologies in earlier educational stages.

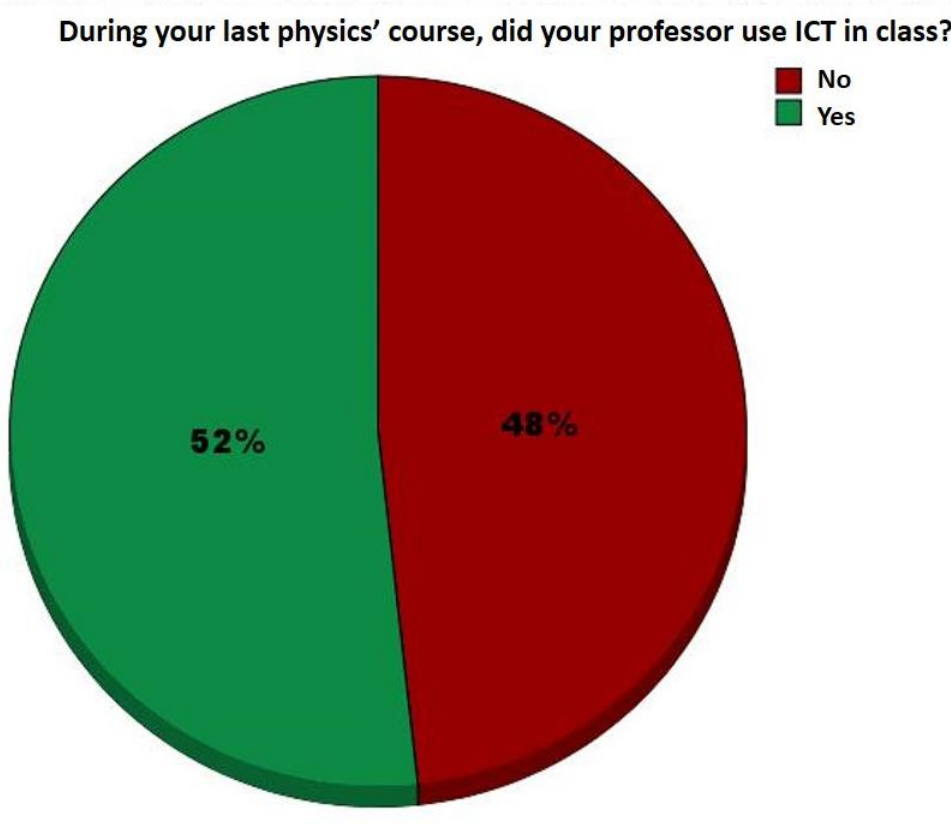

Figure 5. Use of ICT by the physics' professor 
The last axis of analysis of the survey deals with ICT and student motivation. Figure 6 shows that $69 \%$ of students felt motivated in the last physics course they took, while $31 \%$ did not feel motivated by the subject. Although most students report feeling motivated, almost a third were not, which is still a significant number. The reasons for not feeling motivated can be varied: the teacher's way of handling the subject, dislike for the subjects, inadequate learning environment, and personal problems.

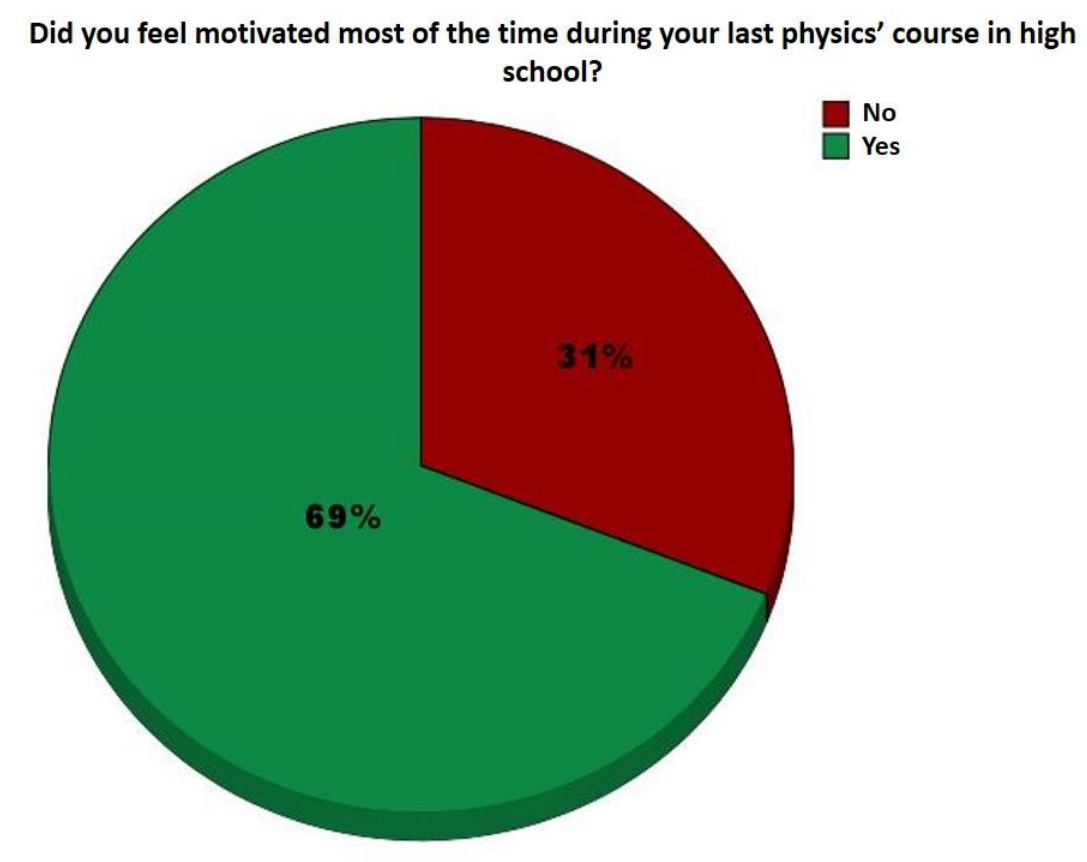

Figure 6. Motivation of students when taking a physics subject

Figure 7 shows that almost $97 \%$ of students feel that the use of technologies in the field of physics will help increase their motivation to learn, while only $3 \%$ believe that it will not. Adolescents today use ICT in their daily lives more and more, so they react favorably to its implementation in learning environments, since most are familiar with its use and do not see it as tedious or boring work. That is why teachers must open themselves to the use of technological tools to motivate their students and establish more flexible learning environments. 


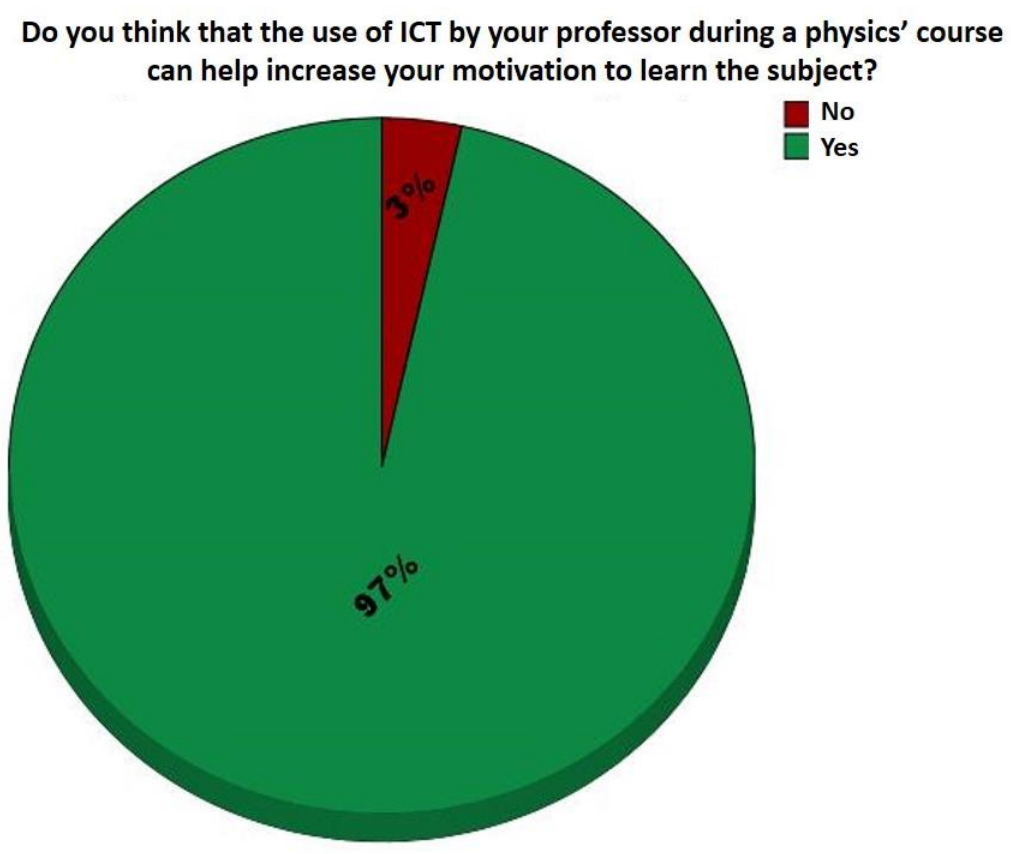

Figure 7. Motivation when using ICT in the physics course.

Figure 8 shows that $97 \%$ of students believe that the use of ICT by their physics teacher will help them better understand the concepts of the subject, while $3 \%$ believe that it will not. It is an identical result to the previous one: we see that motivation is linked to a better understanding of concepts. Being motivated, the student will be able to learn and understand in a more meaningful way the concepts of the physics subject, in this case. As Ausubel mentions in his Theory of Meaningful Learning, meaningful learning involves an affective part without which it cannot be achieved: the learner must have the intention of establishing substantive and non-arbitrary relationships between his cognitive structure and the new educational material to achieve meaningful learning. 


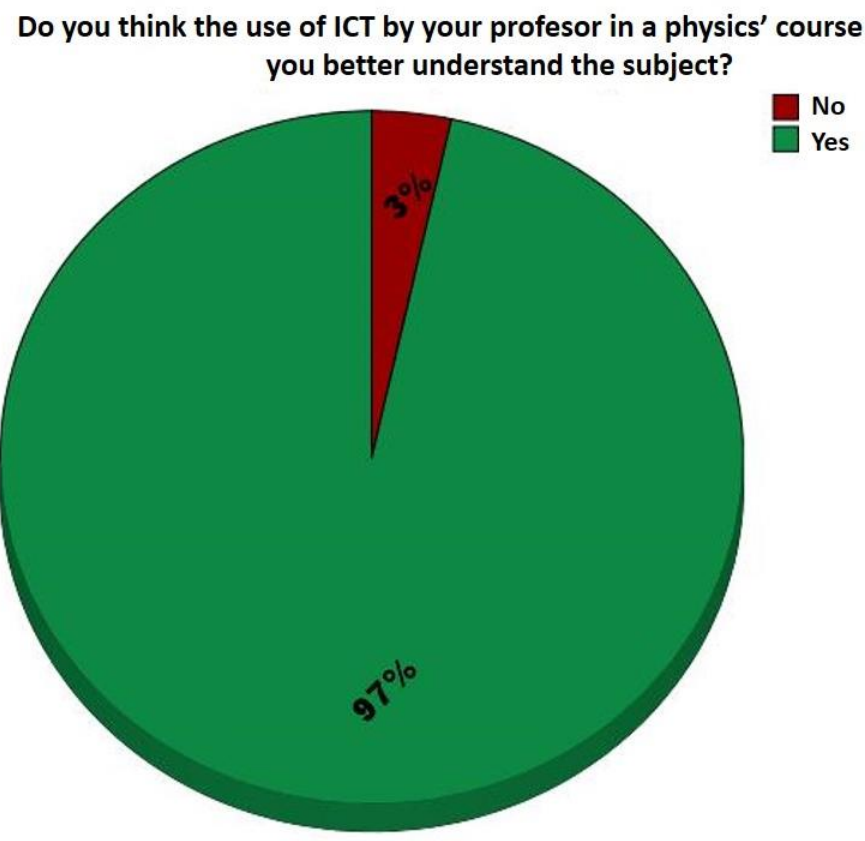

Figure 8. Use of ICT by the physics teacher and student understanding.

An open question was applied in the survey to find out the factors that the student believes most influence their motivation to learn a certain subject, in this case, physics. Figure 9 shows the semantic network created from the analysis of the students' responses.

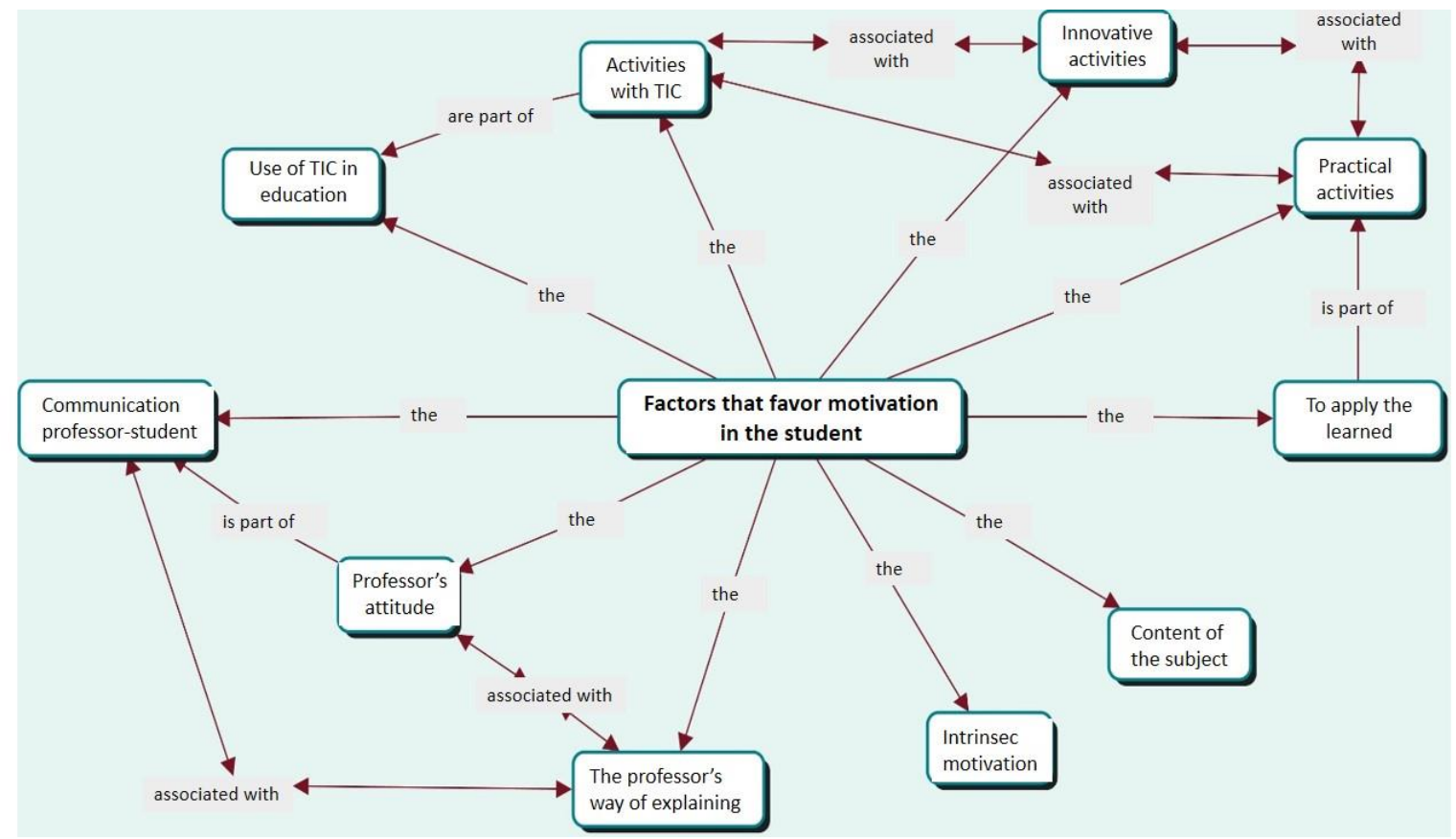

Figure 9. Semantic network on factors that influence motivation towards study. 
As a complement to the above, figure 10 shows which of the factors was most mentioned by the students. The implementation of practical activities was what most students named as a motivating factor. Second was the teacher's way of explaining, followed by the teacher's attitude. They then indicated innovative activities and activities with ICT. It is observed then that students consider it very important to have practical and innovative activities in class, which can be achieved with the help of information and communication

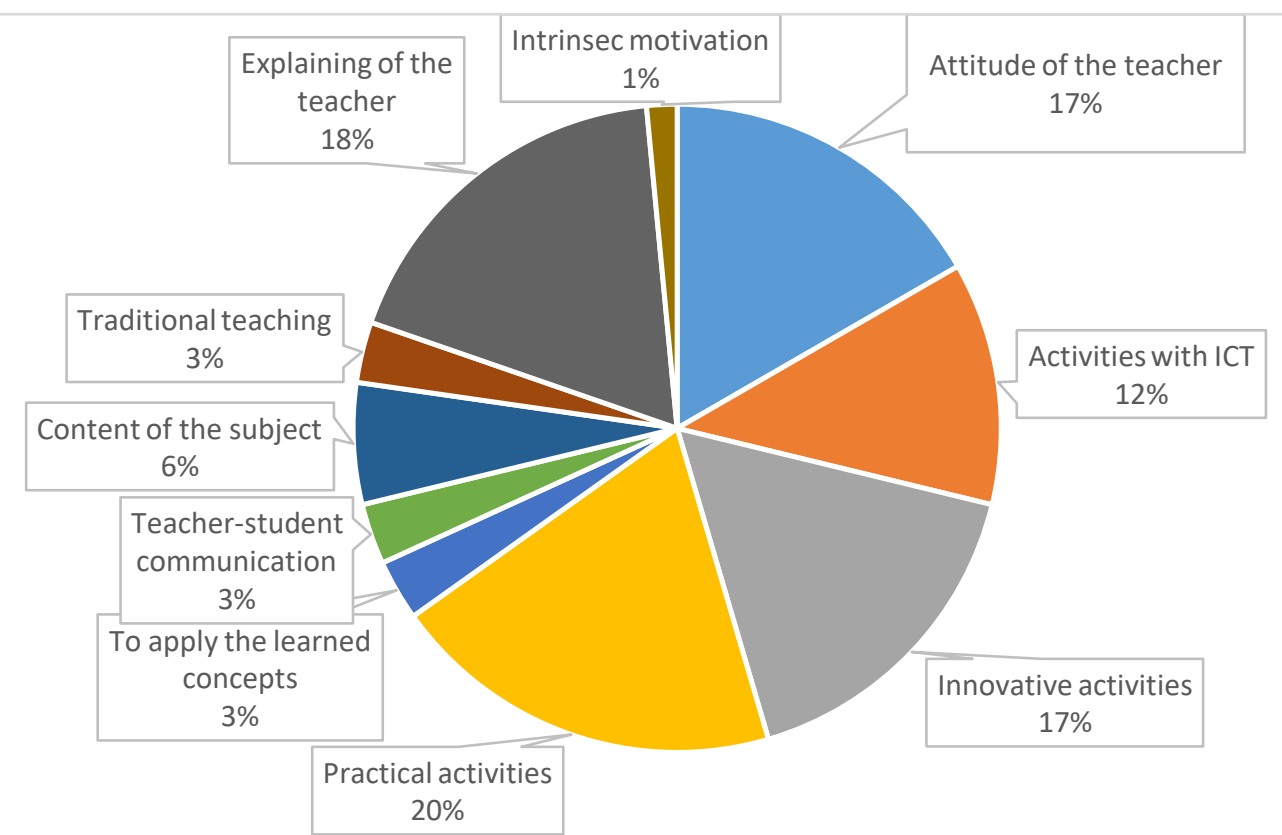

technologies. However, we must not ignore the way in which the concepts are explained to the student, as well as the attitude that the teacher has when teaching his subject.

Figure 10. Factors that favor motivation in the student.

Regarding Phase II, the students were subjected to the test known as the Force Concepts Inventory (FCI) to measure in a certain way their understanding of classical mechanics' concepts. The questionnaire was applied at the beginning and at the end of the course, the data were analyzed with the help of the PhysPort Data Explorer software.

The percentage of correct answers that is calculated for each student has been determined to be a valid measure of the level of mechanics knowledge (Hestenes, Wells, \& Swackhamer, 1992). This percentage is calculated at the beginning and end of the course. For Hestenes and Halloun (1995) a minimum level of valid knowledge and understanding of mechanics is around $60 \%$ of correct answers from the FCI.

29 students took the two questionnaires at the beginning and end of the course. Table 2 presents the results of the analysis. 
Table 2.

Results of the analysis of the FCI test

\begin{tabular}{|l|l|}
\hline Normalized average gain & $0.19 \pm 0.02$ \\
\hline Change effect size & 1.93 \\
\hline Average score & Pre-test $27 \% \pm 3 \%$ \\
& Post-test $40 \% \pm 3 \%$ \\
\hline
\end{tabular}

The normalized gain compares the test scores before (pre-) and after (post-) the course, normalizing the differences between them based on what students still have to learn after taking the pre-test. The formula to calculate the normalized gain for each student is: $g=\frac{\text { post }- \text { pre }}{100 \%-p r e}$. The normalized gain is an important measure to compare the learning of students with a different initial knowledge (Hestenes \& Halloun, 1995).

The effect size of the change compares the pre- and post-test points, and indicates how much they differ. A large change effect indicates that the difference is significant; small change effects mean that the difference is not important. It is calculated using Cohen's $\mathrm{d}: d=$ $\frac{\text { post-pre }}{\text { stdev }}$. Where "stdev" is the standard deviation of the gross profit as a percentage, and "post-pre" is the mean difference between the pre- and post-test scores as a percentage. The standard deviation includes the number of students in the class, so using the size of the change effect allows us to compare the effectiveness of teaching between classes of different sizes.

Courses taught using interactive engagement methods have a higher normalized gain than those taught traditionally. The average normalized gain for courses with interactive engagement is 0.39 and 0.22 for courses with traditional methods.

The average normalized gain of 0.19 for students in the Mechanics Applications course is within the average for courses using traditional teaching methods. Therefore, using only an interactive method, in this case, the use of the CmapTools teaching tool, is not enough to achieve a significant change in student learning.

The size of the effect of change for the investigated class was 1.93, which is considered a large size of change, so there was an important change between the pre and post-test results. Similarly, the average score of the group of students increased from $27 \%$ in the pretest to $40 \%$ in the post-test.

From the results presented, it can be considered that there was an improvement in the understanding of concepts by the students of the Applications of Mechanics group; however, the average percentage of the group in the post-test is still low, compared to the $60 \%$ that is considered minimal to be able to say that the concepts of mechanics are understood.

This is why the researcher believes it is necessary to include more interactive activities with the support of ICT to achieve a truly remarkable change and include concept maps in other stages of the teaching process. 
A second survey was conducted with the students, after the implementation of CmapTools, to obtain information about their opinion regarding the use of concept maps and the application of this technological tool. The results of the survey are shown in Figures 11 and 12.

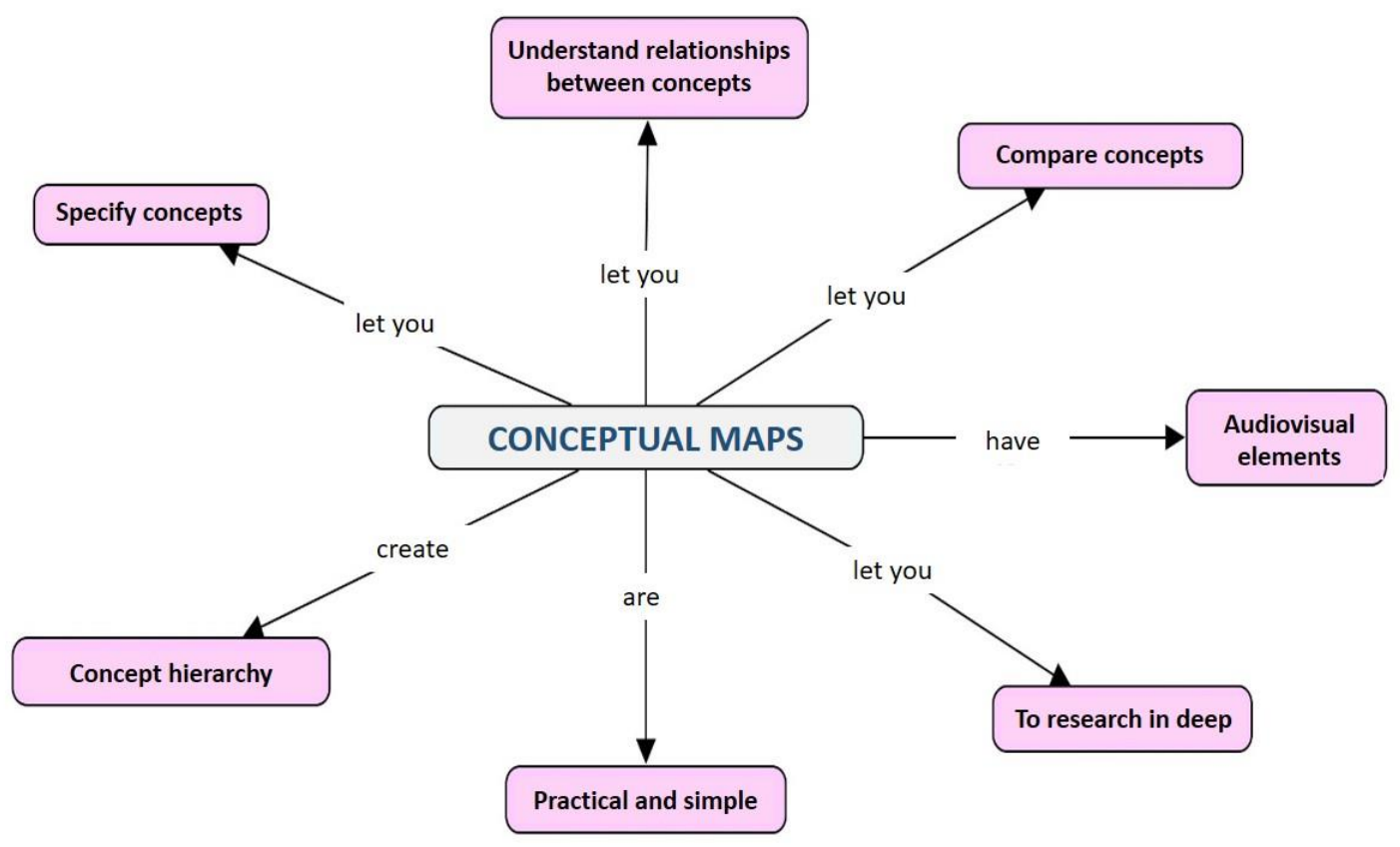

Figure 11. Opinion of the students with respect to the creation of concept maps.

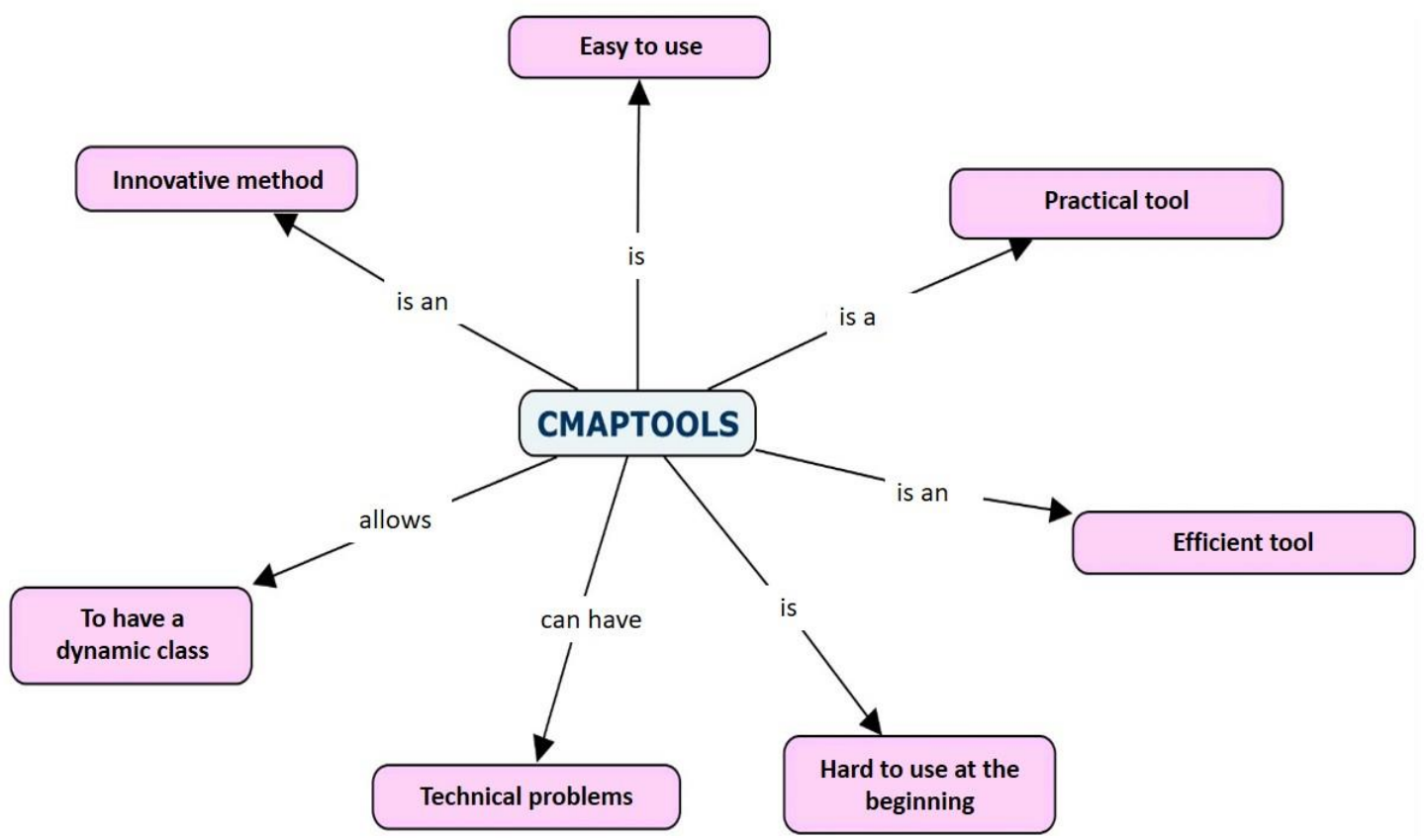

Figure 12. Opinion of the students with respect to the use of the digital tool CmapTools. 
Most of the students mention that the use of concept maps allowed them to understand the relationships between concepts, also to compare concepts and to create a hierarchy. A smaller part of the students believe that concept maps are a practical and simple tool that allows them to investigate a topic in depth and to specify it. Similarly, they talk about the visual way in which creating a concept map helps them understand a topic.

Conclusions. The study implemented the use of concept maps, created with CmapTools, in order for the student to obtain a significant learning of the concepts of classical mechanics. The application of this didactic resource was accompanied by a change of attitude in the teacher, as well as the adaptation of the entire learning environment. The students, by creating concept maps on the basic concepts of mechanics with CmapTools with a good quality of content evaluated with a semantic evaluation rubric, improved their understanding of these concepts, according to the Force Concept Inventory (FCI) questionnaire and also increased their motivation when studying these aspects of mechanics.

So the creation of concept maps with CmapTools has a positive impact on the meaningful learning of the basic concepts of classical mechanics.

The main conclusions of the study are the next:

- At university stage, all students already have certain prior knowledge (which may be correct or incorrect), since they previously studied some physics subject.

- Most students have access to information and communication technologies and mention having used them for educational purposes.

- Specifically in physics subjects, approximately half of the group of students mentions the use of ICT by their teachers. This shows that there is still an important difference between the number of students who use digital tools and the number of teachers who do.

- Today's adolescents use ICT in their daily lives and are increasingly familiar with its use, so they react favorably to its implementation in learning environments and do not see it as tedious or boring work. That is why teachers must open themselves to the use of technological tools to motivate their students and establish more flexible learning environments.

- Motivation is linked to a better understanding of concepts. As Ausubel mentions in his Theory of Meaningful Learning, meaningful learning involves an affective part without which it cannot be achieved: the learner must have the intention of establishing substantive and non-arbitrary relationships between his cognitive structure and the new educational material to achieve meaningful learning.

- Students consider it very important to have practical and innovative activities in class, which can be achieved with the help of information and communication technologies. However, we must not ignore the way in which the concepts are explained to the student, as well as the attitude of the teacher.

- From the exposed results, there was an improvement in the understanding of concepts by the students of the Applications of Mechanics group; however, the 
researcher believes that it is necessary to include more interactive activities with the support of ICT to achieve a truly remarkable change.

- Most of the students mention that the use of concept maps allowed them to understand the relationships between concepts, also compare concepts and create a hierarchy, which contributes to the meaningful learning of these concepts.

- Students believe that concept maps are a practical and simple tool that allows them to investigate a topic in depth and specify it. Similarly, they talk about the visual way in which creating a concept map helps them understand concepts.

- Students also mention technical difficulties when using the computer program. For this reason, it is recommended to start with CmapTools explaining its use in detail to the student, to make the most of its benefits.

- Further research. Some recommendations for further research are:

- To work with more study groups (have one group that uses concept mapping and another that do not, and analyze the differences in the learning achievement)

- To use concept maps at different moments of the educational practice (at the beginning and at the end of the practice)

- To use other software for creating concept maps that may be more dynamic and interactive

- To use other learning tools, such as $V$ diagrams, mental maps, etc.

- To study other aspects of the learning environment that could be affecting student's learning process, for example, the different learning styles.

- To make a more in depth study about motivation and the learning process.

\section{References}

Díaz Barriga, A. F., \& Hernández, R. G. (2002). Estrategias docentes para un aprendizaje significativo. México: McGraw-Hill.

Gómez Mercado, B. I., \& Oyola Mayoral, M. C. (2012). Estrategias didácticas basadas en el uso de TIC aplicadas en la asignatura de física en educación media. Escenarios, 10(1), 17-28.

Hestenes, D., \& Halloun, I. (1995). Interpreting the force concept inventory. A response to Huffman and Heller. The Physics Teacher, 502-506. doi:10.1119/1.2344278

Hestenes, D., Wells, M., \& Swackhamer, G. (1992). Force concept inventory. The Physics Teacher, 141-158. doi:10.1119/1.2343497

Insituto Politécnico Nacional. (s.f.). UPIIZ. Recuperado el 24 de Mayo de 2018, de Mapa curricular Metalúrgica: http://www.zacatecas.ipn.mx/OfertaEducativa/Documents/MAPA_CURRICULAR _METALURGICA.pdf

Novak, J. D. (1991). Clarify with concepts maps. The Science Teacher, 58(7), 45-49.

Novak, J. D. (1997). Retorno a clarificar con mapas conceptuales. En M. A. Moreira, C. Caballero, \& M. L. Rodríguez Palmero, Actas del Encuentro Internacional sobre el Aprendizaje Significativo (págs. 65-84). Burgos, España. 
Novak, J. D., \& Gowin, D. B. (1984). Learning how to learn. Cambridge: Cambridge University Press.

Rodríguez, J. A., Cegarra, J., \& Díaz Caceres, J. J. (2014). Las TICs como estrategias para el aprendizaje del equilibrio químico en estudiantes de educación superior: una experiencia en el curso intensivo del núcleo universitario "Rafael Rangel", en Trujillo. Revista Academia, 13(29), 33-43.

Yanitelli, M. S. (2011). Un cambio significativo en la enseñanza de las ciencias. El uso del ordenador en la resolución de situaciones experimentales de Física en el nivel universitario básico. Tesis de doctorado, Universidad de Burgos, Burgos. 